\title{
BMJ Open Health inequalities in European cities: perceptions and beliefs among local policymakers
}

Joana Morrison, ${ }^{1,2,3}$ Mariona Pons-Vigués, ${ }^{4,5}$ Laia Bécares, ${ }^{6}$ Bo Burström, ${ }^{7}$
Ana Gandarillas, ${ }^{8}$ Felicitas Domínguez-Berjón, ${ }^{8}$ Ėlia Diez, ${ }^{2,3}$ Giuseppe Costa,
Milagros Ruiz, ${ }^{1}$ Hynek Pikhart, ${ }^{1}$ Chiara Marinacci, ${ }^{10,11}$ Rasmus Hoffmann, ${ }^{12}$
Paula Santana, ${ }^{13}$ Carme Borrell, ${ }^{2,3,14}$ and partners from the INEQ-Cities Project

\section{ABSTRACT}

Objective: To describe the knowledge and beliefs of public policymakers on social inequalities in health and policies to reduce them in cities from different parts of Europe during 2010 and 2011.

Design: Phenomenological qualitative study.

Setting: 13 European cities.

Participants: 19 elected politicians and officers with a directive status from 13 European cities.

Main outcome: Policymaker's knowledge and beliefs. Results: Three emerging discourses were identified among the interviewees, depending on the city of the interviewee. Health inequalities were perceived by most policymakers as differences in life-expectancy between population with economic, social and geographical differences. Reducing health inequalities was a priority for the majority of cities which use surveys as sources of information to analyse these. Bureaucracy, funding and population beliefs were the main barriers.

Conclusions: The majority of the interviewed policymakers gave an account of interventions focusing on the immediate determinants and aimed at modifying lifestyles and behaviours in the more disadvantaged classes. More funding should be put towards academic research on effective universal policies, evaluation of their impact and training policymakers and officers on health inequalities in city governments.
CrossMark

For numbered affiliations see end of article.

Correspondence to Joana Morrison; j.morrison@ucl.ac.uk

\section{INTRODUCTION}

Health inequalities in urban environments are complex, ${ }^{12}$ affect the entire population throughout the health gradient ${ }^{3}$ and require a multisectoral approach to address multiple social and economic determinants. ${ }^{4}$ To that effect, although city governments' competences and authorities vary, they are endowed with jurisdiction to develop strategic plans and policies, provide services and deliver interventions which may address health inequalities. $^{5-7}$

\section{Strengths and limitations of this study}

Respondents possibly participated due to their willingness, accessibility as well as interest in the area of health inequalities and therefore may be more sensitive to the issue.

- The data were collected 4 years ago so parties governing in the cities may have changed.

- In some cities, either officers or politicians were interviewed; it might have been more desirable to have one of each for every city.

- As the interviewees were selected by INEQ-Cities partners from each city, these were chosen by opportunistic sampling.

- The interviewees included many examples of their everyday experiences and realities providing rich and detailed information.

- Carrying out the interview, an activity seldom performed previously among policymakers, possibly drew them to review the issue, update their knowledge and learn about the INEQ-Cities project and its results on heath inequalities in their cities.

- Since this is an exploratory study, possibly one of the first of its kind in comparing policymaker's knowledge and beliefs across several cities of Europe, it will hopefully be a stepping stone for further qualitative research on the topic.

- This study has the important advantage of having collected information from quite a large number of cities throughout Europe.

Within governments, policymakers are responsible for decision and policymaking in the form of laws, guidelines and regulations ${ }^{8}$ and their knowledge, beliefs and perceptions are relevant in the implementation of these. It is important to know whether the concept of the social determinants of health inequalities is imbedded in their discourse ${ }^{9}{ }^{10}$ in addition to the information on health issues provided to them as reports or surveys. ${ }^{11}$ These topics, explored in this study, may determine the course of the policy-making 
process. ${ }^{12}$ Furthermore, their perceptions regarding the responsibilities and priorities of city governments and the city government's strategic plans possibly influence the policies in place. ${ }^{13} 14$ These issues along with how policymakers make use of their knowledge will influence decision-making and affect how health inequalities are addressed by city governments. ${ }^{8} 1516$

The majority of studies exploring the knowledge and beliefs of health inequalities have explored lay perceptions ${ }^{17-20}$ and the few studies describing expert beliefs focused on researchers and policymakers working in regional and national governments. ${ }^{9} 2122$ To our knowledge, there are only a small number of studies focusing on policymakers in the city government ${ }^{561423}$ and this is among the first qualitative studies to compare the perceptions of policymakers in different European cities. The use of rigorous qualitative research methods has been on the rise in health services and health policy research $^{24}$ to explore the experiences of participants and the meanings they attribute to them, to contribute new knowledge and to provide new perspectives. ${ }^{25}$ It is consistent with developments in the social and policy sciences at large and has been described to reflect the need for a more in-depth understanding of naturalistic settings, the importance of understanding context and the complexity of implementing social change. ${ }^{26}$ Selecting policymakers from different European cities provided a description of the different sociopolitical realities and contexts according to the participant's daily experiences giving a richer and wider view on reducing health inequalities at the municipal level throughout the continent. Notwithstanding their diversity, the participant cities share important commonalities as European democracies and urban settings, allowing to explore the study object from a new view. Previous studies ${ }^{13}$ in the project have analysed written policy documents in these cities. The objective of this study is to further increase the understanding of social health inequalities and how policies are realised, through the perception and beliefs of public policymakers in 13 European cities during 2010 and 2011.

\section{METHODS}

\section{Methodological development}

We carried out a descriptive and exploratory qualitative research study from a phenomenological perspective ${ }^{27}$ as it sought to capture policymakers' unique accounts of reality in order to capture a breadth of discourses on health inequalities. ${ }^{28}$ Data were collected from 13 cities (Amsterdam, Barcelona, Brussels, Cluj-Napoca, Helsinki, Lisbon, London, Madrid, Paris, Prague, Rotterdam, Stockholm and Turin; see table 1 for information on the cities' profiles) from 11 different European countries participating in the project; Socioeconomic inequalities in mortality: evidence and policies in cities of Europe 2009-2012 (INEQ-Cities) ${ }^{29}$ during the years 2010 and 2011.

\section{Participants and sampling technique}

The study population consisted of 19 public policymakers, selected through opportunistic sampling, ${ }^{28}$ see table 2, working in the aforementioned cities' governments during the research period. A sample of elected politicians which included councillors and or aldermen and high ranked, non-elected, officers was selected. Policymakers were chosen from the health sector as well as other non-health sectors to provide a wider range of discourses. Interviews were performed by INEQ-Cities' partners, who interviewed a maximum of two participants, in their respective cities. Furthermore participants were chosen only if they held a decisionmaking position.

\section{Data collection and generation techniques}

Seventeen semistructured individual interviews and one semistructured interview where two informants participated were carried out from November 2010 to June

Table 1 City profile indicators*

\begin{tabular}{|c|c|c|c|c|c|c|}
\hline City & $\begin{array}{l}\text { Year of the } \\
\text { indicator }\end{array}$ & $\begin{array}{l}\text { Population } \\
\text { aged } 0-14 \%\end{array}$ & $\begin{array}{l}\text { Population aged } \\
65 \text { and older \% }\end{array}$ & $\begin{array}{l}\text { Population aged } \\
16-64 \text { in the labour } \\
\text { market \% }\end{array}$ & Unemployment \% & $\begin{array}{l}\text { Immigrant } \\
\text { population \% }\end{array}$ \\
\hline Amsterdam & 2001 & 16.1 & 11.3 & 72.0 & 13.3 & 48.3 \\
\hline Barcelona & 2005 & 12.3 & 20.8 & 57.2 & 8.7 & 21.5 \\
\hline Brussels & 2001 & 18.3 & 15.4 & 64.9 & 18.2 & 26.3 \\
\hline Helsinki & 2004 & 14.5 & 13.8 & 78.9 & 9.1 & 7.3 \\
\hline Lisbon & 2001 & 14.9 & 15.4 & 73.3 & 7.6 & 5.7 \\
\hline London & 2001 & 20.2 & 12.0 & 67.6 & 5.2 & 24.9 \\
\hline Madrid & 2005 & 12.8 & 18.7 & 74.1 & 8.2 & 14.1 \\
\hline Paris & 2007 & 14.4 & 14.1 & 75.5 & 11.3 & 20.0 \\
\hline Prague & 2006 & 12.3 & 15.6 & 74.8 & 3.5 & 7.6 \\
\hline Rotterdam & 2001 & 17.2 & 14.3 & 69.0 & 9.0 & 45.0 \\
\hline Stockholm & 2005 & 18.0 & 14.1 & 76.0 & 5.3 & 24.3 \\
\hline Turin & 2005 & 11.4 & 23.4 & 67.8 & 11.4 & 5.6 \\
\hline
\end{tabular}


Table 2 Description of the 19 informants*

\begin{tabular}{|c|c|c|c|c|}
\hline Identification (ID) & City (Country) & Status & Profile & Party \\
\hline 1 & Amsterdam (Netherlands) & Officer & Health & NA \\
\hline 2 & Barcelona (Spain) & Politician & Health & Communism, democratic socialism \\
\hline 3 & Barcelona (Spain) & Politician & Non-Health & Eco-socialism \\
\hline 4 & Brussels (Belgium) & Officer & Health & NA \\
\hline 5 & Cluj-Napoca (Romania) & Officer & Health & NA \\
\hline 6 & Helsinki (Finland) & Officer & Health & NA \\
\hline 7 & Lisbon (Portugal) & Politician & Non-Health & Social democracy \\
\hline $8^{*}$ & London (UK) & Officer & Health & NA \\
\hline $9^{*}$ & London (UK) & Officer & Health & NA \\
\hline 10 & Madrid (Spain) & Officer & Health & NA \\
\hline 11 & Madrid (Spain) & Officer & Health & NA \\
\hline 12 & Paris (France) & Officer & Health & NA \\
\hline 13 & Prague (Czech Republic) & Officer & Health & NA \\
\hline 14 & Prague (Czech Republic) & Officer & Health & NA \\
\hline 15 & Rotterdam (Netherlands) & Officer & Non-Health & NA \\
\hline 16 & Stockholm (Sweden) & Politician & Health & Christian democracy (liberal) \\
\hline 17 & Stockholm (Sweden) & Politician & Health & Social democracy \\
\hline 18 & Turin (Italy) & Politician & Non-Health & Social democracy \\
\hline 19 & Turin (Italy) & Politician & Non-Health & Social democracy \\
\hline
\end{tabular}

2011 using an open-ended question topic guide (box 1). The interviews provided information on the participant's knowledge and beliefs of health inequalities and policies to address these, as well as the role of the municipal government. The interview topic guide was developed following the requirements listed in INEQ-Cities' description of work and was further discussed with other project partners. Three pilot interviews were performed in Barcelona to test the topic guides and final versions of the guide were distributed to the project partners in the aforementioned cities who then conducted the interviews. The sessions were carried out in each city's native language and lasted between $45 \mathrm{~min}$ and an hour, where clarification of the topics was needed, some interviewers made city-specific questions. The interviewers belonged to partner groups from the INEQ-Cities project. A data collection manual designed by the authors of this study was sent to each partner and interviewer, providing guidelines on how to perform the interview to ensure that these were carried out in a standardised way. To our knowledge the only participant who did not wish to participate was from the city of Kosice and was therefore not included in the study. Interviews were translated into English by each partner and several sent the transcripts and summaries to the informants for feedback and approval. The summaries and the transcripts were sent to the authors carrying out the analysis in English.

\section{Processing and analysis of information}

All transcripts and summaries were analysed centrally on the basis of a thematic interpretive content analysis ${ }^{28}$ by two researchers (JM and MP-V). Interviews were read numerous times until researchers reached preanalytical intuitions on each of the interviewee's discourses and texts were then coded using predefined and emergent categories. The text was divided following these categories before performing an analysis of the written content and finally the content was articulated into results. Two research members carried out the analysis process independently with the support of Atlas.Ti software, ${ }^{30}$ and compared the main findings with the original data. ${ }^{31}$ The working manuscript was sent to informants through each project partner for approval.

\section{Box 1 Interview topic guide}

\section{Topics}

- Can you explain your point of view on health inequalities in (name of city)?

- Which do you consider are the causes of these health inequalities?

- Is tackling health inequalities a priority in (name of city) or your local area?

- Do you have periodic information on health inequalities and policies designed to reduce them?

- Are there policies aimed at reducing health inequalities in (name of city)? Could you name and describe them?

- Do these policies cover different areas?

- Were these policies designed with the participation of different social agents?

- Sometimes some opportunities arise which may enable the implementation of interventions or policies. Please, can you provide any experience or thoughts about this?

- Which barriers do you face when reducing health inequalities?

- Do you know of policies funded with European structural funds? 


\section{Ethical considerations}

Informed consent was obtained through verbal means and the information was anonymised and confidential. No participants received a salary or reward as participation was completely voluntary and the study received formal ethical approval by a research ethics committee (Hospital del Mar de Barcelona Research Ethics Committee).

\section{RESULTS}

Three emerging discourses were identified among the interviewees, as follows, depending on the city of the interviewee: London's informants focused on structural determinants as the main causes of health inequalities and described universal policies aimed at these, Prague and Cluj-Napoca's interviewees were not as familiar with the concept of the social health inequalities. Informants from other cities had a mixed approach, although they referred to the wider determinants as the causes of health inequalities, they also suggested downstream interventions to address these. It was not possible, however, to distinguish differences in discourses between officers and politicians or health and non-health informants. Table 3 shows a summary of the responses given by each city's participants. Presented below, the results have been arranged in six sections following the major topics explored in the interviews. The informant's identification (ID) can be seen in.

\section{Knowledge on health inequalities and their causes}

Two broad discourses were found within the informant's perceptions and knowledge of health inequalities. The first discourse corresponds to the majority of informants who were aware of such inequalities and described them as differences in health. These were expressed, for example, as differences in life-expectancy.

We have large differences in health: people live five years longer in areas such as Kungsholmen (inner city area of Stockholm municipality) compared to areas such as Järva fältet. Stockholm health politician, ID 16

They also explained that health inequalities existed among the population according to their levels of education or income, gender, age and the neighbourhood in which they lived.

There are factors which relate to education, employment or unemployment, living conditions, income, social relations and ways of life. Also the social exclusion of young people generates inequalities in health. Helsinki health officer, ID 6.

In addition, the interviewee from Lisbon pointed out that inequalities were increasing as did the informant from Brussels who understood them as a gradient.

The second discourse corresponded to informants from Cluj-Napoca and Prague did not have a clear concept on social health inequalities, as described in the quote below.

In this city we cannot talk about this concept. It is estimated that there are no legal criteria to make any differences between individuals in terms of access and use of medical care. Cluj-Napoca health officer, ID 5.

Concerning the causes of inequalities, the majority of the interviewees identified a strong relationship between economic position, educational level and health. Furthermore, low income was perceived as the main cause of unhealthy lifestyle behaviours and reduced access to healthcare which lead to health inequalities. Other social determinants were also highlighted, such as gender, age group, type of household and residential segregation. The current economic crisis and reduced public expenditure were considered to exacerbate the problem and reduce the capacity of action of the local system.

In contrast, interviewees from Prague and Cluj-Napoca considered that health inequalities were mainly a result of individual responsibility.

\section{Reducing health inequalities as a priority for the city government}

Most interviewees reported that reducing health inequalities was an objective of the city government included in either strategic plans or in specific laws. However, interviewees from Prague and Cluj-Napoca did not consider it to be a priority of their municipal governments, whereas Lisbon informant considered it was not a priority even though they thought it should be.

Tackling inequalities in health should be a priority in the Lisbon Metropolitan Area and is not, directly, a hotly debated topic. Lisbon non-health politician, ID 7

The interviewees of Paris and Brussels explained that their city governments did not have jurisdiction over health matters as these are the responsibility of the regional authorities.

In France, health is not a responsibility of the cities, although historically it was the cities that were in charge of sanitary aspects. Paris health officer, ID 12.

That's not easy to answer, as not all the areas are governed on the level of the communities or on the city level. Belgium, health officer, ID 4.

\section{Information on health inequalities}

To monitor health inequalities, the majority of the informants mentioned rely on health surveys which were published periodically in their cities and mortality statistics from their statistics authority.

To track differences in health, a health survey is conducted every four years. Amsterdam health officer, ID 1. 


\begin{tabular}{|c|c|c|c|c|c|c|c|}
\hline City & $\begin{array}{l}\text { Knowledge on HI } \\
\text { and their causes }\end{array}$ & $\begin{array}{l}\text { Reducing } \mathrm{HI} \text { as } \\
\text { a priority for the } \\
\text { city government }\end{array}$ & $\begin{array}{l}\text { Information on } \\
\text { health inequalities }\end{array}$ & $\begin{array}{l}\text { Knowledge on } \\
\text { policies and } \\
\text { programmes }\end{array}$ & $\begin{array}{l}\text { Intersectoral } \\
\text { collaboration/ } \\
\text { participation of social } \\
\text { agents }\end{array}$ & Barriers & Opportunities \\
\hline Amsterdam & $\begin{array}{l}\text { Economic, genetic, } \\
\text { environmental, ethnic } \\
\text { factors }\end{array}$ & $\begin{array}{l}\text { It is a priority, } \\
\text { through changing } \\
\text { economic and } \\
\text { political factors }\end{array}$ & $\begin{array}{l}\text { Health survey, city } \\
\text { memo, } \\
\text { collaboration with } \\
\text { academics }\end{array}$ & $\begin{array}{l}\text { The city has a Health } \\
\text { Plan }\end{array}$ & $\begin{array}{l}\text { There is specific } \\
\text { collaboration with other } \\
\text { sectors }\end{array}$ & $\begin{array}{l}\text { Funding and the } \\
\text { administrative } \\
\text { organisation }\end{array}$ & $\begin{array}{l}\text { Health topics are } \\
\text { placed in the } \\
\text { agenda of } \\
\text { organisations }\end{array}$ \\
\hline Barcelona & $\begin{array}{l}\text { Capitalist economic } \\
\text { system, different life } \\
\text { expectancy between } \\
\text { neighbourhoods, } \\
\text { structural poverty, } \\
\text { traditional and } \\
\text { emerging inequalities }\end{array}$ & $\begin{array}{l}\mathrm{HI} \text { is a priority but } \\
\text { mostly for the } \\
\text { health sector and } \\
\text { at the local level }\end{array}$ & $\begin{array}{l}\text { Annual city health } \\
\text { report and health } \\
\text { policy evaluation. } \\
\text { Social observatory }\end{array}$ & $\begin{array}{l}\text { Urban regeneration } \\
\text { policies. Non-health } \\
\text { policies with health } \\
\text { outcomes, health in } \\
\text { the neighbourhoods } \\
\text { strategy to reduce HI }\end{array}$ & $\begin{array}{l}\text { Not a formal } \\
\text { intersectorality, council } \\
\text { organisation still } \\
\text { compartmentalised. } \\
\text { Eighteen plans with } \\
\text { community action, civil } \\
\text { society }\end{array}$ & $\begin{array}{l}\text { Financial } \\
\text { restraints, factual } \\
\text { powers }\end{array}$ & $\begin{array}{l}\text { Proximity to the } \\
\text { community and } \\
\text { intersectorality }\end{array}$ \\
\hline Brussels & $\begin{array}{l}\text { Gradient in health, } \\
\text { socioeconomic } \\
\text { position, lack of } \\
\text { redistribution } \\
\text { mechanisms, } \\
\text { segregation, personal } \\
\text { traits, access to } \\
\text { healthcare }\end{array}$ & $\begin{array}{l}\text { Reducing } \mathrm{HI} \text { is } \\
\text { an absolute } \\
\text { priority }\end{array}$ & $\begin{array}{l}\text { Death certificates, } \\
\text { census, national } \\
\text { health survey, more } \\
\text { data is needed on } \\
\text { children }\end{array}$ & $\begin{array}{l}\text { No specific policies } \\
\text { aimed at health } \\
\text { inequalities }\end{array}$ & $\begin{array}{l}\text { Collaboration is } \\
\text { transversal with } 3 \\
\text { political structures. } \\
\text { Social agents are } \\
\text { advisory bodies and also } \\
\text { participate in action } \\
\text { plans }\end{array}$ & $\begin{array}{l}\text { The liberal course } \\
\text { of EU. Geographic } \\
\text { proximity of actors }\end{array}$ & $\begin{array}{l}\text { Migrant } \\
\text { population } \\
\text { contribute to } \\
\text { healthy lifestyles }\end{array}$ \\
\hline Cluj-Napoca & $\begin{array}{l}\text { Health inequalities are } \\
\text { not an issue }\end{array}$ & $\begin{array}{l}\text { Reducing } \mathrm{HI} \text { is } \\
\text { not a priority, } \\
\text { health is a right } \\
\text { for all people }\end{array}$ & $\begin{array}{l}\text { The city has the } \\
\text { population health } \\
\text { statistics }\end{array}$ & $\begin{array}{l}\text { There are preventive } \\
\text { measures for the } \\
\text { whole population }\end{array}$ & $\begin{array}{l}\text { There is close } \\
\text { cooperation with } \\
\text { municipalities }\end{array}$ & $\begin{array}{l}\text { Funding and } \\
\text { administrative } \\
\text { restraints are a } \\
\text { barrier }\end{array}$ & \\
\hline Helsinki & $\begin{array}{l}\text { Sex, education, } \\
\text { unemployment, living } \\
\text { conditions, social } \\
\text { relations, exclusion of } \\
\text { young people and } \\
\text { ways of life }\end{array}$ & $\begin{array}{l}\text { Strategy of city } \\
\text { council 2009- } \\
\text { 2012. Resources } \\
\text { directed at } \\
\text { reducing HI }\end{array}$ & $\begin{array}{l}\text { There is some } \\
\text { information } \\
\text { because it is a } \\
\text { strategy of the city }\end{array}$ & $\begin{array}{l}\text { Healthy Helsinki } \\
\text { project to reduce HI. } \\
\text { Non-smoking and } \\
\text { responsible alcohol } \\
\text { consumption } \\
\text { programmes }\end{array}$ & $\begin{array}{l}\text { There is not enough } \\
\text { intersectorality. Steering } \\
\text { committees include } \\
\text { various social agents. } \\
\text { Intersectorality might be } \\
\text { slow }\end{array}$ & $\begin{array}{l}\text { Difficulty to obtain } \\
\text { funding. } \\
\text { Administrative } \\
\text { structures }\end{array}$ & $\begin{array}{l}\text { Funding and } \\
\text { good } \\
\text { cooperation } \\
\text { create } \\
\text { opportunities }\end{array}$ \\
\hline Lisbon & $\begin{array}{l}\text { Socioeconomic, } \\
\text { demographic, income } \\
\text { and age inequalities. } \\
\text { Housing conditions }\end{array}$ & $\begin{array}{l}\text { Reducing } \mathrm{HI} \text { is } \\
\text { not explicitly a } \\
\text { priority, but it } \\
\text { should be. We } \\
\text { have the } \\
\text { Municipal master } \\
\text { plan }\end{array}$ & $\begin{array}{l}\text { There is no } \\
\text { information or } \\
\text { assessment }\end{array}$ & $\begin{array}{l}\text { Policies and plan } \\
\text { targeted at aging }\end{array}$ & $\begin{array}{l}\text { Intersectorality is } \\
\text { inherent in tackling } \\
\text { health inequalities }\end{array}$ & $\begin{array}{l}\text { Cultural, economic } \\
\text { and legislative } \\
\text { obstacles }\end{array}$ & $\begin{array}{l}\text { Initiatives with } \\
\text { multiple } \\
\text { dimensions }\end{array}$ \\
\hline
\end{tabular}




\begin{tabular}{|c|c|c|c|c|c|c|c|}
\hline City & $\begin{array}{l}\text { Knowledge on HI } \\
\text { and their causes }\end{array}$ & $\begin{array}{l}\text { Reducing } \mathrm{HI} \text { as } \\
\text { a priority for the } \\
\text { city government }\end{array}$ & $\begin{array}{l}\text { Information on } \\
\text { health inequalities }\end{array}$ & $\begin{array}{l}\text { Knowledge on } \\
\text { policies and } \\
\text { programmes }\end{array}$ & $\begin{array}{l}\text { Intersectoral } \\
\text { collaboration/ } \\
\text { participation of social } \\
\text { agents }\end{array}$ & Barriers & Opportunities \\
\hline London & $\begin{array}{l}\text { Social determinants in } \\
\text { a global context. Lack } \\
\text { of evidence base of } \\
\text { strategies. Policies } \\
\text { directed at most } \\
\text { deprived instead of all } \\
\text { population }\end{array}$ & $\begin{array}{l}\text { The informants } \\
\text { did not answer } \\
\text { explicitly that } \\
\text { reducing HI was } \\
\text { a priority }\end{array}$ & $\begin{array}{l}\text { There is not a must } \\
\text { on information } \\
\text { data are pieced } \\
\text { together }\end{array}$ & $\begin{array}{l}\text { Primary care } \\
\text { interventions, } \\
\text { employment } \\
\text { programmes, } \\
\text { partnership } \\
\text { approach, no } \\
\text { knowledge on EU } \\
\text { funds }\end{array}$ & $\begin{array}{l}\text { There is intersectoral } \\
\text { work with local } \\
\text { partnerships not only } \\
\text { health services }\end{array}$ & $\begin{array}{l}\text { Little capacity to } \\
\text { influence the } \\
\text { upstream } \\
\text { determinants of } \\
\text { inequalities }\end{array}$ & $\begin{array}{l}\text { Promoting local } \\
\text { integration and } \\
\text { pool resources }\end{array}$ \\
\hline Madrid & $\begin{array}{l}\text { Socioeconomic } \\
\text { inequalities, housing, } \\
\text { lifestyles, education, } \\
\text { Income, cultural } \\
\text { behaviours. } \\
\text { Inequalities at the } \\
\text { district level, access } \\
\text { to healthcare services }\end{array}$ & $\begin{array}{l}\text { A priority to be } \\
\text { dealt with by } \\
\text { healthcare } \\
\text { systems }\end{array}$ & $\begin{array}{l}\text { Yes, through } \\
\text { research and the } \\
\text { annual report }\end{array}$ & $\begin{array}{l}\text { Plan Vallecas to } \\
\text { change behaviours. } \\
\text { Law for health, } \\
\text { programme for the } \\
\text { homeless with } \\
\text { tuberculosis, for } \\
\text { sexual trade workers, } \\
\text { for women of Roma } \\
\text { ethnicity, children at } \\
\text { risk }\end{array}$ & $\begin{array}{l}\text { Plan Vallecas which is } \\
\text { multidisciplinary, } \\
\text { communitary and } \\
\text { participatory. The aim is } \\
\text { to work transversally but } \\
\text { it is difficult. Neighbours' } \\
\text { associations and } \\
\text { participation at the micro } \\
\text { level }\end{array}$ & $\begin{array}{l}\text { Relations with } \\
\text { other institutions, } \\
\text { budget } \\
\text { delimitation, lack } \\
\text { of awareness of } \\
\text { the population, } \\
\text { little information on } \\
\text { the impact of } \\
\text { programmes }\end{array}$ & $\begin{array}{l}\text { To integrate the } \\
\text { actions on the } \\
\text { groups affected } \\
\text { by health } \\
\text { inequalities }\end{array}$ \\
\hline Paris & Access to healthcare & $\begin{array}{l}\text { Health is not } \\
\text { responsibility of } \\
\text { the city } \\
\text { government or a } \\
\text { priority }\end{array}$ & $\begin{array}{l}\text { Epidemiological } \\
\text { information and on } \\
\text { local health issues } \\
\text { for specific } \\
\text { municipalities }\end{array}$ & $\begin{array}{l}\text { City policy: measures } \\
\text { at the city level, } \\
\text { preventive measures, } \\
\text { public Health } \\
\text { programmes in the } \\
\text { neighbourhoods }\end{array}$ & City health workshops & $\begin{array}{l}\text { The consideration } \\
\text { of health in the } \\
\text { context of urban } \\
\text { policy }\end{array}$ & \\
\hline Prague & $\begin{array}{l}\text { Social status, poverty, } \\
\text { chosen lifestyle, } \\
\text { voluntarily socially } \\
\text { excluded }\end{array}$ & $\begin{array}{l}\text { Health } \\
\text { inequalities are } \\
\text { not a priority }\end{array}$ & $\begin{array}{l}\text { National plan of } \\
\text { social politics but } \\
\text { no periodic support }\end{array}$ & $\begin{array}{l}\text { Health } 21 \text {, strategic } \\
\text { plan of Prague }\end{array}$ & $\begin{array}{l}\text { Complex a to work with } \\
\text { different sectors, social } \\
\text { agents make themselves } \\
\text { heard }\end{array}$ & $\begin{array}{l}\text { Legislative and } \\
\text { coordination } \\
\text { issues, financial } \\
\text { barriers }\end{array}$ & $\begin{array}{l}\text { NGO's are very } \\
\text { close to the } \\
\text { socially excluded }\end{array}$ \\
\hline Rotterdam & $\begin{array}{l}\text { Socioeconomic } \\
\text { differences }\end{array}$ & $\begin{array}{l}\text { Yes, with a broad } \\
\text { view on health. } \\
\text { Health is a } \\
\text { precondition for } \\
\text { the life of the city }\end{array}$ & $\begin{array}{l}\text { Health is included } \\
\text { in a general } \\
\text { biannual survey }\end{array}$ & $\begin{array}{l}\text { Directed at unhealthy } \\
\text { behaviour of low } \\
\text { SES, air quality and } \\
\text { traffic, health plan }\end{array}$ & $\begin{array}{l}\text { Work, participation, } \\
\text { education. "Healthy in } \\
\text { the city": city health plan. } \\
\text { "From complaint to } \\
\text { strength", depression } \\
\text { and diabetes. } \\
\text { Many joint projects but } \\
\text { no collaboration with } \\
\text { social actors }\end{array}$ & $\begin{array}{l}\text { Long timeframe in } \\
\text { cooperating with } \\
\text { other networks. } \\
\text { Different levels in } \\
\text { institutions have } \\
\text { trouble } \\
\text { communicating }\end{array}$ & $\begin{array}{l}\text { Benefits of } \\
\text { cooperation }\end{array}$ \\
\hline
\end{tabular}




\begin{tabular}{|c|c|c|c|c|c|c|c|}
\hline City & $\begin{array}{l}\text { Knowledge on } \mathrm{HI} \\
\text { and their causes }\end{array}$ & $\begin{array}{l}\text { Reducing } \mathrm{HI} \text { as } \\
\text { a priority for the } \\
\text { city government }\end{array}$ & $\begin{array}{l}\text { Information on } \\
\text { health inequalities }\end{array}$ & $\begin{array}{l}\text { Knowledge on } \\
\text { policies and } \\
\text { programmes }\end{array}$ & $\begin{array}{l}\text { Intersectoral } \\
\text { collaboration/ } \\
\text { participation of social } \\
\text { agents }\end{array}$ & Barriers & Opportunities \\
\hline Stockholm & $\begin{array}{l}\text { Structural differences: } \\
\text { housing segregation, } \\
\text { education level, age } \\
\text { group, income, } \\
\text { migration criminal } \\
\text { acts/safety and living } \\
\text { conditions. Health } \\
\text { inequalities in } \\
\text { Stockholm are very } \\
\text { large }\end{array}$ & $\begin{array}{l}\text { Based on } \\
\text { healthcare } \\
\text { services. } \\
\text { Legislation is } \\
\text { there but the } \\
\text { educated are the } \\
\text { ones who } \\
\text { benefit. } \\
\text { Accessibility to } \\
\text { healthcare is the } \\
\text { highest priority }\end{array}$ & $\begin{array}{l}\text { Public health } \\
\text { survey produced } \\
\text { every four years, } \\
\text { review of } \\
\text { healthcare services, } \\
\text { Karolinska Institute } \\
\text { Public Health } \\
\text { Academy reports }\end{array}$ & $\begin{array}{l}\text { Wide range of choice } \\
\text { of health providers, } \\
\text { addressed at } \\
\text { behavioural and } \\
\text { cultural determinants, } \\
\text { resources for } \\
\text { prevention are too } \\
\text { small }\end{array}$ & $\begin{array}{l}\text { Action plan for health, } \\
\text { hard for actors to } \\
\text { cooperate voluntary } \\
\text { organisations which } \\
\text { strengthen the } \\
\text { community but } \\
\text { non-existent in } \\
\text { participatory process }\end{array}$ & $\begin{array}{l}\text { Lack of } \\
\text { competence, } \\
\text { knowledge and } \\
\text { methods to } \\
\text { change } \\
\text { behaviours }\end{array}$ & $\begin{array}{l}\text { Resources, } \\
\text { Evidenced } \\
\text { based health } \\
\text { prevention, } \\
\text { Engaged people } \\
\text { working in health } \\
\text { centres }\end{array}$ \\
\hline Turin & $\begin{array}{l}\text { Housing conditions, } \\
\text { overcrowding, } \\
\text { economic and } \\
\text { employment crisis, } \\
\text { deterioration of social } \\
\text { conditions }\end{array}$ & $\begin{array}{l}\text { The city has a } \\
\text { direct and } \\
\text { privileged } \\
\text { approach to } \\
\text { dealing with } \\
\text { inequality but } \\
\text { there are } \\
\text { conflicts of } \\
\text { interest }\end{array}$ & $\begin{array}{l}\text { No use of } \\
\text { effectiveness } \\
\text { indicators for } \\
\text { evaluation and } \\
\text { modification of } \\
\text { policies }\end{array}$ & $\begin{array}{l}\text { Policies not } \\
\text { addressed at specific } \\
\text { groups, traffic } \\
\text { calming and public } \\
\text { transport } \\
\text { development, } \\
\text { security, social } \\
\text { housing, local welfare } \\
\text { strategies }\end{array}$ & $\begin{array}{l}\text { Sentinel events arise } \\
\text { interest but there is a } \\
\text { conflict of interests in the } \\
\text { political administration }\end{array}$ & $\begin{array}{l}\text { Structural policies } \\
\text { tend to be slow }\end{array}$ & $\begin{array}{l}\text { Social } \\
\text { cooperatives for } \\
\text { housing by } \\
\text { improving } \\
\text { existing assets }\end{array}$ \\
\hline
\end{tabular}

EU, European Union; HI, health inequalities; NGOs, non-governmental organisations; SES, socioeconomic status. 
London's interviewees described the need to integrate the different sources of information into one to make access to information easier. Informants from Lisbon and Prague declared not having information or assessment of health inequalities. Furthermore, the interviewee from Cluj-Napoca explained that periodic data of health inequalities were not available as this concept was not applicable.

\section{Knowledge on policies and programmes implemented}

When asked about their knowledge of policies that address health inequalities, policymakers described actions aimed at deprived populations and at modifying attitudes and unhealthy behaviours, such as smoking and poor diets. They emphasised the importance of preventive measures and health promotion and education. Policies to improve access to healthcare services were also quoted as an important means to reduce health inequalities by most interviewees. However, the informants from London highlighted the need to address health inequalities throughout the general population rather than focusing on the most deprived sectors and developing long-term policies aimed at the social determinants, not only proximal factors, such as physical activity and fruit intake. Moreover, the informant from Turin highlighted local interventions aimed at addressing unemployment and the interviewee from Madrid described tackling health inequalities at the local level.

We have to work on the processes...I'm talking from the micro level, which is where I have more experience, but I think that's where the solution lies, in the micro level. Madrid health politician, ID 10.

The informants from Prague, however, did not mention any policies implemented by their city government and referred to national health plans as a reference for health-related issues.

\section{Inter-sectoral collaboration and participation of social agents in policymaking}

Interviewees from Madrid, London, Rotterdam and Lisbon referred to strategic plans which fostered intersectoral collaboration between different administrations, citizens' and non-profit associations and established local partnerships. Barcelona and Turin, in turn, described inter-sectoral collaboration established only between two sectors, for example between health and welfare or health and education. While Lisbon cited examples of housing policies for groups at risk of exclusion, some informants suggested that inter-sectoral collaboration slowed down the policy-making process and perceived that having different sectors collaborate proved to be difficult.

Yes. Action on inequalities in health is synonymous with disciplinary cross-cutting. In this sense, this theme is incorporated in several areas such as education, social service, environmental and cultural policies, among others, addressed in the municipal master plan. Lisbon, non-health politician, ID 7 .

With respect to community organisations participating in the policy-making process, the majority of the informants thought their city governments collaborated with these; however, informants from Rotterdam, Turin and Stockholm considered it was very limited.

The social networks exist but they need public support. There is no doubt that there should be more shared responsibility among private sector and public services or welfare systems. Turin non-health politician, ID 18.

\section{Barriers and opportunities encountered}

One of the principal barriers described was the lack of awareness on changing unhealthy lifestyles among the population. Informants from Stockholm and Lisbon considered the obstacles addressing health inequalities to be essentially related to imbedded cultural beliefs which made adopting healthier lifestyles difficult. Bureaucratic restraints and resistance from other levels of the administration along with miscommunication with the private sector as well as budget restrictions were described as important barriers by the majority of interviewees. London's interviewee explained that implementing financial policies from within a city government was complicated in the context of globalisation.

We come across them all the time and a very important one is the financial issue. Every year we have less money and the crisis only makes it worse. Barcelona health politician, ID 2.

Informants also referred to opportunities which enabled policy implementation. For example, the interviewees from Barcelona and Rotterdam made reference to working at the community level or with different sectors which led to learning opportunities. Community groups were seen as especially important in liaising with hard to reach groups. The interviewee from Brussels suggested that the migrant population promoted healthy lifestyle behaviours, as some of their customs had healthy components.

There are definitely opportunities. Other services have problems as well and see the benefits of cooperation with groups who work with migrant population. Brussels health officer ID 4.

\section{DISCUSSION}

To the best of our knowledge, this is the first study to explore policymakers' perceptions on health inequalities and policies to reduce these throughout various European cities from diverse geographical areas and with different socioeconomic and political contexts. Three discourses were identified depending on the city of the interviewee: (1) London's approach focused on upstream determinants and policies; (2) Cluj-Napoca 
and Prague's approach where informants were less acquainted with social health inequalities and (3) the rest of the cities' informants who perceived health inequalities as differences in life-expectancy among the population defined by their economic, social and geographical background. Regarding the causes of health inequalities, these were seen as being caused by lowincome levels, unhealthy lifestyle behaviours and barriers in accessing healthcare. Most of the informants agreed that reducing these inequalities was a priority of their local governments and referred to periodic surveys as information sources to monitor them. Nearly all policies and interventions were targeted at modifying health behaviours and some relied upon inter-sectoral collaboration. Furthermore, bureaucracy, funding and the population's attitudes and beliefs towards healthy lifestyles were considered important barriers.

The majority of informants described upstream determinants such as socioeconomic and structural factors as the causes of health inequalities, but nevertheless focused on describing downstream policies and programmes. This could be due to the fact that the informants work in city governments and even though they are aware of the main causes of health inequalities, their daily routines involve work with downstream policies and programmes. In this regard, some city councils may have limited authority over upstream determinants ${ }^{42}$ or over health when it is under the authority of higher levels of government; such was the case of Paris and Brussels. In this sense, policymakers seemed to refer to what was within their mandate, so even if they understood structural determinants were important in addressing health inequalities, the activities they described were focused within their own jurisdiction. Downstream interventions targeted at disadvantaged populations such as some of the ones described by the interviewees, which do not aim at reducing inequalities throughout the whole gradient, may end up being diluted into multiple small downstream initiatives and are less effective in reducing health inequalities. ${ }^{33} 34$ This also carries the risk of health inequalities becoming the responsibility of each individual, which is already an existing trend, ${ }^{35}$ and downplaying the responsibilities and competences of the city government which will constitute a barrier for the local city governments in tackling inequalities. Moreover it has been widely argued that if interventions are not delivered carefully, they are likely to increase inequalities as those who are most in need, might not benefit from the intervention. ${ }^{36}$ However, as described elsewhere, ${ }^{5}$ the majority of research on health inequalities relates to downstream determinants and focuses on individual lifestyle factors, ${ }^{37}$ thus little information is provided to policymakers on the wider determinants and the underlying causes of the causes of health inequalities. ${ }^{38}$

Furthermore, with the exception of Brussels' and London's interviewees, the concept of the socioeconomic gradient in health was not present among respondents; their understanding of reducing health inequalities connoted reducing the differences between the most deprived groups and the rest of the city's population. Therefore, their discourses did not seem to acknowledge that inequalities affect the entire population and not only the most disadvantaged populations. ${ }^{39}$

Except for Lisbon and the Central-eastern European cities, most of the informants mentioned having access to information on health inequalities through periodical surveys or health reports. Those with access to regular information on health inequalities would be more likely to see the underpinning structural causes and be willing to act upon them. Furthermore, Prague and Cluj-Napoca expressed not being aware of the existence of inequalities in their cities possibly because they were not as familiar with the concept. There are some relevant studies on health inequalities in the Czech Republic ${ }^{40}{ }^{41}$ and in Romania. ${ }^{42}$ Nevertheless, the overarching INEQ-Cities project $^{29}$ will provide the cities included in the project with further data on health inequalities at the small area level. Data on health indicators and inequalities is important for various reasons: to understand how causal pathways are established and to design effective policies and interventions. ${ }^{4}{ }^{11}$ While elsewhere it was concluded that researchers do not provide policymakers with befitting and timely information ${ }^{15} 2243$ constantly requiring more evidence runs the risk of delaying having to face the problem and making decisions. ${ }^{12}$ Nevertheless, additional evidence on the social determinants of health, and particularly on effective interventions and policies is important.

The majority of the informants understood that reducing health inequalities was a priority for their city government. However, only the city governments of Amsterdam, Barcelona, Helsinki, London, Madrid, Rotterdam, Lisbon and Stockholm had health plans, and within these only London has a specific plan for reducing health inequalities, as has also been described elsewhere. ${ }^{13}$ Our findings partly reflect the different stages of awareness and action undertaken in the cities as it describes a spectrum of different approaches towards inequalities adopted by countries throughout Europe. We understand that a strong political will is inherent to tackling health inequalities along with supplying policymakers with information on the social determinants and how the gradient operates. ${ }^{33}$

Many of the participants described participation between sectors at some level, even though not all cities showed the same involvement. A study carried out also within the INEQ-Cities project analysing policy documents of some of the cities included in this study showed similar results. ${ }^{13}$ Another study ${ }^{23}$ observed that the structure of political responsibilities in the Canadian context offered important constraints for inter-sectoral collaboration. Encouraging the continuation of collaborative strategies may have a substantial impact on reducing health inequalities, previous research has shown that inter-sectoral collaboration between the health and other sectors is essential to achieving health outcomes 
in a more effective way than from the health sector alone. ${ }^{44}$ Fewer cities described participatory processes and collaborating with social agents. Including other stakeholders in policy-making processes is an important step to city governance and empowerment, both decisive in reducing health inequalities more effectively. ${ }^{34} 45$ However, there are many different barriers which policymakers encounter when trying to establish collaborative relationships such as an overall lack of awareness of health inequalities among those who work in the city government, difficulties to coordinate with other authorities, a lack of mandate and limited resources. ${ }^{8} 16$

Along with the barriers mentioned above, lack of awareness on health inequalities and bureaucratic restraints were the main barriers to reduce health inequalities as quoted by the interviewees and have been categorised elsewhere as ideological and institutional. ${ }^{23}$ Institutional limitations are related to values, attitudes and opinions; one possible explanation why this approach has been underlined is that informants seemed to focus mostly on lifestyles and healthy behaviours instead of structural determinants as the causes of health inequalities. Furthermore, the second group of barriers referring to rigid bureaucracy and funding might also be reinforced by the ideological barriers and exacerbated by the social and financial crisis and subsequent austerity measures.

\section{Limitations and strengths}

It should be also taken into account that in some cases, the politicians interviewed gave political discourses and it was a difficult task to make them follow the topics. Participants were selected through an opportunistic sampling, they might not be the most representative informants in their fields; other respondents might have wider knowledge on the subject or they possibly participated due to their willingness, accessibility as well as interest in the area of health inequalities and therefore may be more sensitive to the issue. The interviews were carried out by different interviewers from each city in their native language so that participants could express themselves more freely. The results of politicians and officers have been presented together as we found no differences in their discourses. Nevertheless, the informants included in this study were selected following the pre-established criteria so both elected and non-elected informants were highly positioned in their municipal government's structure and had decision-making competences. The data were collected 4 years ago so parties governing in the cities may have changed and the elected officials may not be working in decision-making positions at the present moment. However, describing these beliefs provides very valuable information on the governance of cities given the key role of policymakers.

As a relevant strength of the study, the interviewees included many examples of their everyday experiences and realities providing rich and detailed information. They expressed their own beliefs and describing them provides very valuable information on the governance of cities given the key role of policymakers. Moreover, carrying out the interview, an activity seldom performed previously, probably drew politicians to review the issue, update their knowledge and learn about the INEQ-Cities project (INEQ-Cities 2012). The findings of the present study to some extent mirrors the findings of the analysis of health policy documents in the same cities, and illustrates the different stages at which cities are concerning work on health inequalities. ${ }^{13} 46$ This exploratory study, possibly one of the first of its kind in comparing policymakers' knowledge and beliefs across several cities of Europe, will hopefully be a stepping stone for further studies and also has the important advantage of having information from quite a large number of cities.

\section{CONCLUSIONS AND RECOMIMENDATIONS}

The majority of the interviewed policymakers gave an account of interventions focusing on the immediate determinants and aimed at modifying lifestyles and behaviours in the more disadvantaged classes. Some described intersectoral action explicitly and for most cities reducing health inequalities was a priority and policymakers had access to periodic information.

Future collaboration between the research centres from Cluj-Napoca and Prague and their local governments could possibly foster more awareness about health inequalities and their causes and the importance of addressing them. Providing decision makers from the municipal governments with information on policies aimed at addressing upstream determinants alongside health indicators should be encouraged further to promote knowledge on their role in addressing health inequalities.

More funding should be put towards academic research on effective universal policies, evaluation of their impact and training policymakers and officers on health inequalities in city governments. Further advocacy must be carried out to place health inequalities and their implications in the municipal government's agenda and in city health plans.

\section{Author affiliations}

${ }^{1}$ Department of Epidemiology and Public Health, University College London, London, UK

${ }^{2}$ CIBER de Epidemiología y Salud Pública (CIBERESP), Spain

${ }^{3}$ Agència de Salut Pública de Barcelona, Barcelona, Spain

${ }^{4}$ Institut Universitari d'Investigació en Atenció Primària Jordi Gol (IDIAP Jordi Gol), Barcelona, Spain

${ }^{5}$ Universitat de Girona, Girona, Spain

${ }^{6}$ School of Social Sciences, University of Manchester, Manchester, UK

${ }^{7}$ Karolinska Institutet, Stockholm, Sweden

${ }^{8}$ Subdirección General de Promoción de la Salud y Prevención. Consejería de Sanidad. Comunidad de Madrid (Subdirectorate-General for Health Promotion and Prevention. Madrid Regional Health Authority), Spain

${ }^{9}$ Department of Clinical and Biological Science, University of Turin, Turin, Italy

${ }^{10}$ Epidemiology Department, Local Health Unit T03, Turin, Italy

${ }^{11}$ Ministry of Health, Italy, Rome, Italy

${ }^{12}$ Erasmus Medical Centre, Rotterdam, The Netherlands

${ }^{13}$ Centro de Estudos de Geografia e Ordenamento do Território (CEGOT), Departamento de Geografia, Universidade de Coimbra, Coimbra , Portugal

${ }^{14}$ Universitat Pompeu Fabra, Barcelona, Spain 
Acknowledgements The authors would like to thank the informants who participated in the interviews and the interviewers who carried them out and all the partners involved in the INEQ-Cities project. This article forms part of Joana Morrison's Doctoral Thesis.

Contributors All authors made substantial contributions to conception and design of the study and interviews. The majority carried out the interviews in their own cities and translated these and provided a summary or transcription. Once the data were analysed by the coordinating centre, the authors interpreted the results and provided critical feedback as well as sending the results to informants and providing the coordinating centre with comments or suggestions made by them. Authors also participated in drafting the article and reviewed it critically several times, making substantial comments and suggestions regarding form, analysis and concepts. Authors also reviewed and approved the final version of the manuscript and provided their approval for publication.

Funding This article has been partially funded by the project: INEQ-Cities, 'Socioeconomic inequalities in mortality: evidence and policies of cities of Europe'; project funded by the Executive Agency for Health and ConsumersDG Sanco (Commission of the European Union), project no2008 1213 and CIBER de Epidemiología y Salud Pública.

Competing interests None.

Ethics approval The Hospital del Mar de Barcelona (Barcelona Mar Hospital) Ethics committee.

Provenance and peer review Not commissioned; externally peer reviewed.

Data sharing statement No additional data are available.

Open Access This is an Open Access article distributed in accordance with the Creative Commons Attribution Non Commercial (CC BY-NC 3.0) license, which permits others to distribute, remix, adapt, build upon this work noncommercially, and license their derivative works on different terms, provided the original work is properly cited and the use is non-commercial. See: http:// creativecommons.org/licenses/by-nc/3.0/

\section{REFERENCES}

1. Kilroy A. Intra-urban spatial inequalities: cities as 'urban regions' World development report. MIT and UNDP. 2009, 1-27.

2. UN-HABITAT/WHO. Hidden cities: unmasking and overcoming health inequities in urban settings. 2010. http://www.hiddencities.org/ downloads/WHO UN-HABITAT Hidden Cities Web.pdf (accessed 12 Nov 2013)

3. Commission on Social Determinants of Health, WHO. Closing the gap in a generation. Health equity through action on the social determinants of health. http://whqlibdoc.who.int/hq/2008/WHO_IER CSDH_08.1_eng.pdf (accessed 8 Feb 2014).

4. World Health Organization (WHO). Centre for Health Development. Our cities, our health, our future. Acting on social determinants for health equity in urban settings. Report to the WHO Commission on Social Determinants of Health from the Knowledge Network on Urban Settings. 2008. http://www.who.int/social_determinants/ resources/knus final report 052008.pdf (accessed 14 Aug 2013).

5. Collins PA. Do great local minds think alike? Comparing perceptions of the social determinants of health between non-profit and governmental actors in two Canadian cities. Health Educ Res 2012;27:371-84.

6. Collins PA, Hayes MV. Examining the capacities of municipal governments to reduce health inequities: a survey of municipa actors' perceptions in Metro Vancouver. Can J Public Health 2013;104:304-10.

7. Borrell C, Pons-Vigués M, Morrison J, et al. Factors and processes influencing health inequalities in urban areas. $J$ Epidemiol Community Health 2013;67:389-91.

8. Lavis JN. Ideas, policy learning and policy change: the determinantsof-health synthesis in Canada and the United Kingdom 1998.

9. Lavis JN. Ideas at the margin or marginalized ideas? Nonmedical determinants of health in Canada. Health Aff (Millwood) 2002;21:107-12.

10. Liverpool WHO Collaborating Centre for Policy Research on Social Determinants of Health. How can the health equity impact of universal policies be evaluated? Insights into approaches and next steps. Edited by: Milton B, Moonan M, Taylor-Robinson D, Whitehead M. pp 1-56. WHO, Copenhagen, 2011
11. Borrell C, Bartoll X, García-Altés A, et al. A quarter of a century of health reports in Barcelona: a commitment to transparency and a tool for action. Rev Esp Salud Publica 2011;85:449-58.

12. Whitehead M. Diffusion of ideas on social inequalities in health: a European perspective. Milbank Q 1998;76:469-92.

13. Borrell C, Morrison J, Burstrom B, et al. Comparison of health policy documents of European cities: are they oriented to reduce inequalities in health? J Public Health Policy 2013;34:100-20.

14. Collins PA, Hayes MV. The role of urban municipal governments in reducing health inequities: a meta-narrative mapping analysis. Int J Equity Health 2010;9:13.

15. Lavis JN, Posada FB, Haines A, et al. Use of research to inform public policymaking. Lancet 2004;364:1615-21.

16. Lavis JN. Research, public policymaking, and knowledge-translation processes: Canadian efforts to build bridges. J Contin Educ Health Prof 2006;26:37-45.

17. Davidson $R$, Mitchell $R$, Hunt $K$. Location, location, location: the role of experience of disadvantage in lay perceptions of area inequalities in health. Health Place 2008;2:167-81.

18. Macintyre S, McKay L, Ellaway A. Lay concepts of the relative importance of different influences on health; are there major socio-demographic variations? Health Educ Res 2006;21:731-39.

19. Macintyre S. Evidence in the development of health policy. Public Health 2012;126:217-19.

20. Popay J, Bennett S, Thomas C, et al. Beyond 'beer, fags, egg and chips'? Exploring lay understandings of social inequalities in health. Sociol Health IIIn 2003;25:1-23.

21. Lavis JN, Ross SE, Stoddart GL, et al. Do Canadian civil servants care about the health of populations? Am J Public Health 2003:93:658-63.

22. Petticrew M, Whitehead M, Macintyre SJ, et al. Evidence for public health policy on inequalities: 1 : the reality according to policymakers. J Epidemiol Community Health 2004;58:811-16.

23. Collins PA, Abelson J, Eyles JD. Knowledge into action? Understanding ideological barriers to addressing health inequalities at the local level. Health Policy 2007;80:158-71.

24. Sofaer S. Qualitative research methods. Int J Qual Health Care 2002;14:329-36.

25. Tong A, Sainsbury $P$, Craig J. Consolidated criteria for reporting qualitative research (COREQ): a 32-item checklist for interviews and focus groups. Int J Qual Health Care 2007;19:349-57.

26. Shortell SM. The emergence of qualitative methods in health services research. Health Serv Res 1999;34:1083-90.

27. Reeves S, Albert M, Kuper A, et al. Why use theories in qualitative research? BMJ 2008;337:49.

28. Maxwell JA. Qualitative research design. An interactive approach. Qualitative research design. An interactive approach. 2nd edn. Thousand Oaks, CA: SAGE, 2005.

29. INEQ-Cities Socio-economic inequalities in mortality: evidence and policies in cities of Europe. INEQ-Cities Atlas. https://www.ucl.ac.uk/ ineqcities/atlas (accessed 10 Oct 2013).

30. ATLAS.ti. Atlas. ti Qualitative data analysis software. 2010-2011 Scientific Software Development GmbH.

31. Mays N, Pope C. Qualitative research in health care-assessing quality in qualitative research. BMJ 2000;320:50-2.

32. Vlahov D, Freudenberg N, Proietti F, et al. Urban as a determinant of health. J Urban Health 2007;84:16-26.

33. Marmot M, Commission Social Determinants Hlt. Achieving health equity: from root causes to fair outcomes. Lancet 2007;370: 21153-63.

34. The Commission to Reduce Social Inequalities in Health in Spain. A proposal of policies and interventions to reduce social inequalities in health in Spain.Commission to Reduce Social Inequalities in Health in Spain. Gac Sanit 2012;26: 182-89.

35. WHO. Review of social determinants and the health divide in the WHO European Region. Review chair: Michael Marmot. Report prepared by UCL Institute of Health Equity, 1-188. 2013.

36. Lorenc T, Petticrew M, Welch V, et al. What types of interventions generate inequalities? Evidence from systematic reviews. $J$ Epidemiol Community Health 2013;67:190-93.

37. Whitehead M, Dahlgren G. What can be done about inequalities in health? Lancet 1991;338:1059-63.

38. Rose G. Sick individuals and sick populations. Int J Epidemiol 1985;14:32-8

39. Whitehead M, Dahlgren G. Concepts and principles for tackling social inequities in health. Levelling up (part 1). Denmark, 2006.

40. Dzurova D, Spilkova J, Pikhart H. Social inequalities in alcohol consumption in the Czech Republic: a multilevel analysis. Health Place 2010;16:590-97. 
41. Pikhart $H$, Drbohlav D, Dzurova D. The self-reported health of legal and illegal/irregular immigrants in the Czech Republic. Int $J$ Public Health 2010;55:401-11.

42. Florescu L, Balanica G, Vremera T, et al. Cross-sectional study to evaluate risk factors in infant malnutrition. Rev Med Chir Soc Med Nat lasi 2011;115:699-704.

43. Petticrew M, Roberts H. Systematic reviews-do they 'work' in informing decision-making around health inequalities? Health Econ Policy Law 2008;3:197-211.
44. Solar O, Irwin A. A conceptual framework for action on the social determinants of health. Discussion paper for the Commission on Social Determinants of Health, 2007.

45. Bambra C, Joyce KE, Bellis MA, et al. Reducing health inequalities in priority public health conditions: Using rapid review to develop proposals for evidence-based policy. J Public Health 2010;32:496-505.

46. Diez E, Morrison J, Pons-Vigués $M$, et al. Municipal interventions against inequalities in health: The view of their managers. Scand $J$ Public Health [Epub ahead of print 22 Apr 2014]. 